\title{
O zapomnianym polskim tłumaczeniu tzw. Parafrazy Modlitwy Pańskiej Ludolfa z Saksonii ${ }^{*}$
}

\section{On a forgotten Polish translation of the Paraphrase of Pater Noster by Ludolphus of Saxony}

\author{
Dorota Masłej \\ Wydział Filologii Polskiej i Klasycznej, Uniwersytet im. Adama Mickiewicza w Poznaniu, \\ ul. Fredry 10, 61-701 Poznań, Polska; \\ maslej.dorota@gmail.com
}

\begin{abstract}
Abstrakt
Celem artykułu jest analiza nieznanego tłumaczenia parafrazy Modlitwy Pańskiej Ludolfa z Saksonii na język wernakularny. Autor proponuje odmienny sposób spojrzenia na glosy do łacińskiego tekstu: nie są one jedynie pojedynczymi dopiskami, ale tworzą artystyczne tłumaczenie łacińskiej podstawy. Całość zapisków jest interpretowana jako tekst otwarty, możliwy do realizacji na kilka sposobów: w całości po łacinie, w całości po polsku oraz jako tekst dwujęzyczny.
\end{abstract}

Slowa kluczowe: Ludolf z Saksonii; Ludolf Kartuz; parafraza Modlitwy Pańskiej; Vita Ihesu Christi; tekst otwarty; wersja interlinearna; glosa; thumaczenie w średniowieczu.

\begin{abstract}
The aim of the article is to analyse an unknown vernacular translation of the Paraphrase of Pater noster by Ludolphus of Saxony. The author proposes a new way of thinking about glosses to the Latin text. It is believed that glosses are not only singular words but they form the artistic translation of the Latin base. The jottings can be interpreted as an open text, which could have been realised in many ways: as a Latin text, a Polish text or a bilingual, Polish-Latin text.
\end{abstract}

Keywords: Ludolphus of Saxony; Ludolph the Carthusian; paraphrase of Pater noster; Vita Ihesu Christi; open text; interlinear version; gloss; translation in the Middle Ages.

Za podstawę materiałową badań historycznojęzykowych dotyczących polskiego średniowiecza uznaje się stosunkowo nieliczne zachowane ${ }^{1}$ polskie teksty

* Autor uzyskał środki finansowe w ramach finansowania stypendium doktorskiego z Narodowego Centrum Nauki (2017/24/T/HS2/00027) i jest stypendystą Fundacji Uniwersytetu im. Adama Mickiewicza w Poznaniu na rok akademicki 2017/2018.

${ }^{1}$ Wiesław Wydra ocenia, że do dziś zachowało się ok. 5\% tekstów średniowiecznych (Mika 2015a). 
oraz, coraz częściej włączane do analiz lub stanowiące ich podstawę², glosy znajdujące się w wielu zarówno polskich, jak i łacińskich rękopisach.

Zwykle badacze nazywają poszczególne zabytki tekstami, jednak pytanie o to, czym jest tekst w średniowieczu, zostało dopiero niedawno sformułowane jako odrębny problem badawczy (Mika 2013, 2015a, 2015b, Masłej 2017a). Podobnie w sposób intuicyjny najczęściej stosuje się termin glosa. Podstawowym kryterium identyfikacji i klasyfikacji glos jest miejsce ich wpisania na kartę (to jest też podstawą najpowszechniejszego podziału dopisków ze względu na ich ulokowanie na karcie: na glosy marginalne, interlinearne i wciągnięte $w$ tekst $^{3}$ ), a zatem kryterium ,zewnętrzne” wobec glosowanego tekstu. Tylko w wypadku tych ostatnich, glos wciągniętych do tekstu, stosuje się kryteria „wewnętrzne”, które umożliwiają uznanie danego elementu za nieistniejący w pierwszym (poprzednim) tekście (pratekście, poprzedniej kopii) dopisek (glosy w tekście rozpoznaje się m.in. poprzez wyrazy i wyrażenia je wprowadzające, takie jak to czusz, czusz, albo, to jest (Twardzik 1994; Mika, Twardzik 2011)4, choć te nie zawsze sygnalizują element nieprzynależący genetycznie, w pierwszej redakcji, do tekstu Stramczewska 2015). Dopiski interlinearne i marginalne, o ile wiążą się z tekstem głównym, uznaje się zaś za glosy wyłącznie ze względu na miejsce ich wpisania.

Powstaje zatem problem, czy podjęcie decyzji wynikającej tylko z zastosowania kryterium zewnętrznego jest możliwe wobec wszystkich średniowiecznych zabytków zawierających polskie dopiski do tekstu głównego. Istnieją bowiem takie rękopisy, w których szczególnie liczne dopiski tworzą na przykład „prawie kompletny przekład wersetów 1-9 XXI rozdziału Ewangelii wg św. Mateusza”tak Wojciech Ryszard Rzepka i Wiesław Wydra piszą o fragmencie rękopisu Biblioteki Narodowej, sygn. 3019 III (Rzepka, Wydra 2004: 84).

W wypadku tego typu zabytków szczególnie ważne wydaje się postawienie podstawowego pytania o ich istotę. $\mathrm{W}$ zależności od podjętej $\mathrm{w}$ tym względzie decyzji (najczęściej bezpośrednio widocznej w proponowanym sposobie wydania zabytku - Masłej 2017b) i od uznania dopisków za glosy lub za tekst inne będzie bowiem podejście do badanego rękopisu, inne będą również wnioski płynące $\mathrm{z}$ analiz.

Do takich zabytków zaliczyć można zapomniany, nieobecny w świadomości badaczy fragment rękopisu Cesarskiej Biblioteki Publicznej w Petersburgu, sygn.

${ }^{2}$ Szacuje się, że glosowane zabytki stanowią ok. 64\% materiału stanowiącego podstawę Stownika staropolskiego. Zestawienie to przedstawił Maciej Leńczuk w referacie Historia języka - konieczności i możliwości badań źródłowych w XXI wieku (Kongres Historyków Języka: Językoznawstwo historyczne - w poszanowaniu przeszłości, w trosce o przyszlość, Katowice, 13-15.04.2016).

${ }^{3}$ Oczywiście istnieje kilka typologii glos ze względu na różne kryteria, o części z nich pisze Mariusz Leńczuk (2010), przywołany jednak przeze mnie podział jest powszechnie przyjęty i uznany za podstawowy, niejako nadrzędny wobec pozostałych (zob. np. Masłej, w druku).

${ }^{4}$ Katalog wyrazów wprowadzających glosy na przykładzie Rozmyślania przemyskiego sporządziła Agata Gesner (2011). 
I Q 199, będący przedmiotem tego artykułu. Sam rękopis się nie zachował, a jego zawartość znamy tylko z opisu Aleksandra Brücknera: ,zawiera traktaty teologiczne, między innymi mgr. Bartholomei de Yasel, a na k. 177 wykład pacierza z glosami między wierszami tejże ręki" (1897: 271). Celem artykułu jest pokazanie, że obiekt badań (dokładnie: jego polskojęzyczna część) nie jest, jak dotąd sądzono, zbiorem glos. Aby to uczynić, ważna jest właściwa identyfikacja podstawy źródłowej, do której poczyniono polskie dopiski.

Łaciński tekst, który Brückner nazwał „wykładem pacierza”, jest w rzeczywistości nierozpoznanym dotąd fragmentem tzw. parafrazy Modlitwy Pańskiej autorstwa Ludolfa z Saksonii, zwanego też Ludolfem Kartuzem, niemieckiego dominikanina z XIV wieku (o jego życiu pisze szczegółowo Krzysztof Bielawski - 2002). Znany jest on przede wszystkim z monumentalnego dzieła Vita Jesu Christi, którego fragmentem jest wspomniany tekst. Bielawski, zauważył, że „w Polsce dzieło kartuza było mało znane” (2002: 235). Wydaje się jednak, że sąd ten należy zweryfikować. Vita Christi mogło być jednym ze źródeł ówczesnej wiedzy: zostało przywołane wprost w kazaniach Paterka, który napisał o jego autorze: „mistrz żywota chrystusowego Ludolphus”, jest jednym ze źródeł polskiego apokryfu, Rozmyślań dominikańskich (Dobrzeniecki 1965: 39), wreszcie - w XVI wieku znajdowało się także w bibliotece Zygmunta Augusta5 ${ }^{5}$ co pozwala wnioskować o randze tego dzieła w ówczesnej Rzeczpospolitej. Sama modlitwa zbudowana na tekście Ojcze nasz - zamykająca rozdział 37. pierwszej księgi Vita Jesu Christi ${ }^{6}$ - musiała być znana w Polsce już na początku XV wieku, gdyż zapisał ją w swoich notatkach Jakub z Piotrkowa (rękopis datowany na lata 1410 -1440 - Masłej 2015), a także skryba omawianego rękopisu z biblioteki Czackiego. Już zapisanie tego tekstu obok traktatów Barłłomieja z Jasła, filozofa i teologa, świadczy o jego znaczeniu. Podzielam bowiem pogląd bliski np. Monice Opalińskiej, badającej staroangielskie parafrazy Ojcze nasz, że

Praca nad tekstem źródłowym powinna oznaczać stały powrót do rękopisu - pierwszego świadka nieraz zawiłej historii literackiego zabytku. Tylko tam, w otoczeniu innych

${ }^{5}$ „Ostatnie dzieło wymieniam umyślnie, chociaż ono z naszem Rozmyślaniem bezpośrednio się nie łączy; przedrukowano bowiem tego olbrzyma średniowiecznego (XIV wieku) u nas jeszcze w r. $1750 \mathrm{z}$ taką starannością i ozdobnością, jakiej by po wczesnych drukarniach naszych nikt się nie spodziewał, p. t. Excelsum et excellentissimum opus Vitae Iesu Christi... per Ludolphum de Saxonia ordinis Carthus. collectum, liberalitate Sim. Wosiński canon cathedr. posnan. reincusum, 1750, Posnaniae, typis academicis, folio, dwie części, 924 i 702 str. Z licznych wydań tego dzieła posiada biblioteka król. w Berlinie między innemi i egzemplarz z biblioteki Zygmunta Augusta, kupiony widocznie przez Trzecieskiego dla króla; jest to wydanie «Ludolphus Chartusianus in Christi Servatoris vitam. Lugduni 1544». Na okładce nachodzą się znane wyciski: (na okładce tylnej) Sigismundi Augusti Regis Poloniae Monumentum 1550; (na przedniej) Lud. Cart. vita Chr. W tekście są przypiski spółczesnej ręki, drobniutkim charakterem, czy jednego z kaznodziei królewskich, czy może Lizmanina, bo że nie Górnicki do tego foliantu zaglądał, to pewna. Zresztą egzemplarz zachowany tak, jakby dopiero niedawno wyszedł z pod prasy - liczniejszych czytelników nie znalazł" (Brückner 1900: 15).

${ }^{6}$ Tłumaczenie całego rozdziału znajduje się w artykule Bielawskiego (2002). 
dokumentów, często nieprzypadkowych, we właściwej dla epoki ornamentyce i pierwotnym układzie na pergaminowej karcie, tekst jest zaświadczony w naturalnym dla siebie kontekście (Opalińska 2010: 299).

Łaciński tekst stanowi, jak powiedziano wcześniej, trzecią część rozdziału 37. (oratio), a poprzedza go wykład dotyczący Pater noster ${ }^{7}$. Zapewne ten fragment uniezależnił się od całego dzieła Vita Christi i zaczął funkcjonować samodzielnie w wielu redakcjach i wariantach (Masłej 2015, przyp. 17). Wydaje się, że proces ten dotyczy zresztą funkcjonowania tekstu Ludolfa z Saksonii nie tylko na ziemiach polskich. Siegfried Heinimann zauważył: „Der Text [von der erweiteren gereimter Version des Paternoster - D.M.] wurde früh in mehrere Sprachen übersetzt. Grossen Erfolg hatte das Buch im iberoromanischen Raum [...]" (Heinimann 1988: 80) $)^{8}$ XV-wieczne tłumaczenia na różne języki znalazły się w przygotowanej przez Heinimanna edycji romańskich tekstów Ojcze nasz.

Mimo wielu funkcjonujących obok siebie wersji parafrazy, niezmienna jest kompozycja tego tekstu: modlitwa opiera się na poszczególnych cząstkach Pater noster, zbudowano ją na układzie elementów dookreślających, rozwijających odpowiedni fragment Ojcze nasz.

Brückner w Rozprawach Akademii Umiejętności wydał pierwszą część wspomnianego fragmentu dzieła Ludolfa z Saksonii. W związku z tym, że nie mamy dostępu do rękopisu, nie możemy stwierdzić, czy w rękopisie zapisano całą tzw. parafrazę Modlitwy Pańskiej (a może i inne ustępy z Vita Christi). Być może wydawca przepisał tylko tę część, nad którą znajdowały się polskie dopiski, być może zaś tylko ona znajdowała się w rękopisie. Także druga hipoteza jest możliwa, ponieważ przytoczony przez Brücknera fragment stanowi pewną całość: obejmuje trzy pierwsze prośby z Modlitwy Pańskiej dzielonej tradycyjnie w średniowieczu właśnie na trzy prośby dotyczące Boga i życia wiecznego oraz cztery związane z życiem doczesnym ${ }^{9}$. Zapisanie tylko tego fragmentu może zatem nie być przypadkowe i mieć swoje uzasadnienie $\mathrm{w}$ tradycyjnym podziale.

Przyjrzyjmy się obecnemu w rękopisie Cesarskiej Biblioteki Publicznej fragmentowi podstawy łacińskiej:

Pater noster excelsus in creacione, suavis in amore, dives in hereditate. Qui es in coelis speculum eternitatis, corona iocunditatis, thezaurus eterne felicitatis. Sanctificetur nomen tuum mel in ore, melos in aure, iubilus in corde. Adveniat regnum tuum iocundum sine permixcione, tranquillum sine perturbacione, securum sine permissione. Fiat vol-

${ }^{7}$ Każdy rozdział Vita Christi, jak wskazuje Bielawski, jest zbudowany na schemacie lectio, meditatio, oratio, contemplatio (2002: 234).

${ }^{8}$ We wstępie badacz pisze także o „,wersjach w językach narodowych” tej parafrazy („Eine erste Ausname [die Prosaparaphrasen - D.M.] bilded die gereimte Fassung Lufolfs von Sachsen [...], mit deren vulgärsprachlichen Versionen wir dieschmalen Abteilungen des Katalanischen, Portugiesischen und Provenzalischen erweitern" (Heinimann 1988: 17).

9 Tradycja takiego podziału była żywa w średniowieczu, czego dowodem jest część zapisów Pater noster (Masłej 2016: 34-35, 107). 
untas tua sicut in celis et in terra ut ea que odis odiamus, qui oderunt, qui offendunt iniuria verborum, molestia operum aut allacione rerum.

W tekście wyraźnie widoczna jest jego retoryczna struktura:

\section{Pater noster}

(1) excelsus in creacione (2) suavis in amore (3) dives in hereditate Qui es in coelis

(1) speculum eternitatis (2) corona iocunditatis (3) thezaurus eterne felicitatis

\section{Sanctificetur nomen tuum}

(1) mel in ore (2) melos in aure (3) iubilus in corde

\section{Adveniat regnum tuum}

(1) iocundum sine permixcione (2) tranquillum sine perturbacione (3) securum sine permissione

\section{Fiat voluntas tua sicut in celis et in terra}

ut ea (1) que odis odiamus

\section{(2) qui oderunt (3) qui offendunt}

(1) iniuria verborum (2) molestia operum (3) aut allacione rerum.

Składa się on z paralelnie zbudowanych, rymujących się elementów rozwijających fragmenty modlitwy. Początkowe wezwanie: Pater noster uzupełnione jest o przymiotniki opisujące przymioty Boga, rozwinięcie w drugim wersie także dotyczy Boga, tu opisywanego wyrażeniami metaforycznymi zbudowanymi z rzeczowników. W wersach trzecim i czwartym (w dwóch pierwszych prośbach) elementami wyjaśnianymi, stojącymi w centrum uwagi, są wyrażenia nomen tuum oraz regnum tuum. Dopiero w wypadku trzeciej prośby metaforycznie opisuje się, objaśnia czynność (fiat voluntas tua), co ma swoje odzwierciedlenie w bardziej skomplikowanej strukturze. Rozwinięcie tekstu Pater noster składa się w tym wypadku ze zdania podrzędnego wprowadzonego spójnikiem $u t$ z kolejnymi zdaniami podrzędnymi, z których ostatnie uzupełnione jest trzema okolicznikami sposobu (co odpowiada trójkowej strukturze, na której opiera się cała modlitwa).

Tekst z rękopisu Cesarskiej Biblioteki Publicznej, sygn. I Q 199, znany, jak powiedziano wcześniej, wyłącznie z wydania Brücknera, wygląda następująco:

Pater noster excelsus in creacione suavis in amore dives in hereditate sswyrchowani wstworzenu lascawy wmiloscy bogati wdzyedzystwe $\}$; qui es in coelis speculum eternitatis $\{$ swyerzczadlo wyecznoscy\} Corona iocunditatis \{radoscy\} thezaurus eterne felicitatis $\{$ scarb wyecznego sczascza $\} ..$. mel in ore $\{$ myod wusczyech $\}$ melos in aure \{slotkoscz wusye\} iubilus in corde \{radoscz wsyerczu\}; adveniat regnum tuum iocundum sine permixcione \{radość przeszamyeszanya\}, tranquillum sine perturbacione \{spocoyne przenagabana\}, securum sine permissione \{przespyeczne przes przepuszczena\}; fiat voluntas tua sicut in celis et in terra ut ea que odis odiamus aby to czo nyenawyczyss nyenawidzelibichom $\}$; qui oderunt qui offendunt iniuria verborum mo- 
lestia operum aut allacione rerum \{nyenawydzyely zagnewaly zacrzywdzenym slow... skutków (vczinkow) abo wszuczym rzeczy (wzięcim)\} (Brückner 1897: 271).

Fragmenty polskie - jak wiemy z krótkiego opisu karty - zostały zapisane $\mathrm{W}$ interlinii. $\mathrm{W}$ edycji oznaczono je nawiasami klamrowymi. W ostatnim dopisku dwa słowa w obrębie nawiasu klamrowego zostały ujęte w nawiasy okrągłe. Można domniemywać, że są to glosy ,piętrowe”, dopisane do zapisanych już w interlinii fragmentów. Druga z nich pozwala zrozumieć wyraz przetransliterowany przez wydawcę jako wszuczym.

Przytoczony przez Brücknera tekst jest niepełny. W dwóch miejscach wielokropkami wydawca zasugerował opuszczenie jakiegoś fragmentu, być może jego nieczytelność - jedno z tych miejsc znajduje się w tekście głównym, ale ze względu na to, że udało się zidentyfikować podstawę łacińską, można je uzupełnić (jest to brakujący werset z Ojcze nasz: Sancfiticetur nomen tuum). Transkrypcja fragmentów polskich ${ }^{10} \mathrm{z}$ koniecznymi uzupełnieniami łacińskimi wygląda następująco:

$<$ Pater noster $>$ Zwirchowany w stworzeniu, łaskawy w miłości, bogaty w dziedzictwie.

$<$ Qui es in caelis $>$ zwierciadło wieczności, <corona > radości, skarb wiecznego szczęścia.

$<$ Sanctificetur nomen tuum $>$ Miód w uściech, słodkość w usze $<$ ch $>$, radość w sercu.

$<$ Adveniat regnum tuum $>$ radość przez zamieszania, spokojne przez nagabania, przespieczne przez przepuszczenia.

$<$ Fiat voluntas tua sicut in caelis et in terra $>$ aby to, co nienawidzisz, nienawidzielibychom, <qui > nienawidzieli, <qui> zagniewali zakrzywdzeniem słów, <molestia $>$ skutków (uczynków) albo wszuczym (wzięciem) rzeczy.

Pisarz nie przetłumaczył (i nie zapisał w interlinii) łacińskich fragmentów $P a$ ter noster, wyrazu corona - co może wynikać z tożsamości zapisu (swoistej homografii) łacińskiego słowa $\mathrm{z}$ polskim odpowiednikiem ${ }^{11}$ - oraz zaimków dzierżawczych w ostatnim fragmencie. W tym brakuje też (w miejscu oznaczonym przez Brücknera wielokropkiem) nominalizacji w ostatniej konstrukcji trójkowej (molestia). Uzupełnienie interlinearnych zapisek o te elementy pozwala dostrzec w nich nie pojedyncze glosy odnoszące się do łacińskiej modlitwy, ale tekst, który jest jej wiernym przekładem, co obrazuje poniższe zestawienie:

[1]

excelsus in creacione - zwirchowany w stworzeniu

suavis in amore - łaskawy w miłości

dives in hereditate - bogaty w dziedzictwie

10 Tylko wyraz odczytany przez wydawcę jako wszuczym pozostawiono w transliteracji.

${ }^{11}$ Głoskę [k] często oddawano w zapisie literą $c$. 
[2]

speculum eternitatis - zwierciadło wieczności

corona iocunditatis - radości

thezaurus eterne felicitatis - skarb wiecznego szczęścia

[3]

mel in ore - miód w uściech

melos in aure - słodkość w usze $<$ ch $>$

iubilus in corde - radość w sercu

[4]

iocundum sine permixcione - radość prze zamieszania

tranquillum sine perturbacione - spokojne prze nagabania

securum sine permissione - przespieczne przez przepuszczenia

\section{[5]}

ut ea que odis odiamus - aby to, co nienawidzisz, nienawidzilibychom

qui oderunt qui offendunt iniuria verborum $-<$ qui $>$ nienawidzieli, $<$ qui $>$ zagniewali zakrzywdzeniem słów

molestia operum aut allacione rerum $-<$ molestia $>$ skutków (uczynków) albo wszuczym (wzięciem) rzeczy

Jedynym odstępstwem od wiernego tłumaczenia jest przełożenie łacińskiego wyrażenia melos in aure przez stodkość $w$ usze $<$ ch $>$. Prawdopodobnie skryba skojarzył łaciński wyraz melos ('pieśń) z występującym w poprzedniej cząstce rzeczownikiem mel ('miód'), stąd jego pomyłka. Pozostałe fragmenty są dokładnie oddane po polsku, z zachowaniem metaforyki, ale także - co istotne - kompozycji tekstu źródłowego oraz walorów artystycznych. Podobnie jak w źródle, na rozwinięcie fragmentów tekstu Ojcze nasz składają się zawsze trzy paralelnie zbudowane elementy (bardziej skomplikowaną strukturę ma uzupełnienie zbudowane na trzeciej prośbie - element 5). Mają one określony rytm (w obrębie poszczególnych konstrukcji trójkowych liczba sylab w składających się na nie elementach jest taka sama lub różni się najwyżej o jedną zgłoskę), który wzmocniony jest rymami, choćby w rozwinięciu prośby Adveniat regnum tuum, gdzie każda cząstka kończy się nominalizacją ${ }^{12}$. W polskim tłumaczeniu dba się także o jego walory brzmieniowe, co widać na przykład w zastosowaniu aliteracji we fragmencie przespieczne przez przepuszczenia.

Wyłącznie w ostatniej cząstce: , $<$ Fiat voluntas tua sicut in caelis et in terra $>$ aby to, co nienawidzisz, nienawidzielibychom, <qui $>$ nienawidzieli, <qui $>$ za-

${ }_{12}$ Zdzisława Krążyńska, Tomasz Mika i Agnieszka Słoboda zauważają bardzo ważną w tym kontekście cechę nominalizacji: „W polszczyźnie religijnej, np. kazaniach czy narracjach apokryficznych, nominalizacje są związane przede wszystkim ze stosowaniem zabiegów o charakterze retorycznym, są bowiem niezwykle wygodnym sposobem budowania całostek retorycznych" (2015: 149). 
gniewali zakrzywdzeniem słów, <molestia> skutków (uczynków) albo wszuczym (wzięciem) rzeczy" tekst polski trzeba uzupełnić słowami z tekstu głównego, ale tylko dwa z nich - dwukrotnie występujący w źródle zaimek qui - były rzeczywiście nieobecne $\mathrm{w}$ dopiskach $\mathrm{w}$ interlinii. W miejscu molestia Brückner umieścił wielokropek, co może oznaczać, że w rękopisie zapisano odpowiadający łacińskiemu słowu polski wyraz, ale był on dla wydawcy nieczytelny. Warto zauważyć, że mimo skomplikowania, tłumacz dokładnie oddał łacińską strukturę:

ut ea (1) que odis odiamus - aby to, co nienawidzisz, nienawidzielibychom

(2) qui oderunt $-<$ qui $>$ ('tych, którzy') nienawidzieli

(3) qui offendunt - <qui > ('tych, którzy') zagniewali

(1) iniuria verborum - zakrzywdzeniem słów

(2) molestia operum $-<$ molestia $>$ ('utrudnieniem') skutków (uczynków)

(3) aut allacione rerum - albo wszuczym (wzięciem) rzeczy

W całej części polskiej nie przekładano tylko fragmentów pochodzących z $\mathrm{Pa}$ ter noster, co jednak nie dziwi. Był to tekst powszechnie znany, obecny w liturgii w dużej mierze po łacinie (zalecenia odmawiania modlitwy Ojcze nasz po polsku z wiernymi dotyczyły przede wszystkim kazania i modlitwy po nim). Ponadto polski przekład Ojcze nasz, którego nauczano od XIII wieku, był doskonale znany, co pozwala sądzić, że tłumaczenie łacińskiego tekstu Pater noster na żywo nie sprawiłoby trudności kapłanowi lub osobie odmawiającej modlitwę autorstwa Ludolfa z Saksonii. Nie było zatem potrzeby, aby w interlinii zapisywać odpowiednie fragmenty polskie. Warto też pamiętać o tym, że nie wiemy, w jaki sposób wyglądała omawiana karta rękopisu. Być może fragmenty pochodzące z Modlitwy Pańskiej były graficznie wyodrębnione, co umacniałoby przedstawioną hipotezę.

Tak szczegółowy opis zabytku pozwolił wyodrębnić w nim dwa zasadnicze obszary: pierwszy to łaciński tekst główny (modlitwa autorstwa Ludolfa z Saksonii), składający się z kanonicznego tekstu Pater noster oraz poetyckich rozwinięć poszczególnych fragmentów; drugi stanowią polskie dopiski do tychże rozwinięć.

Zanim odpowiemy na pytanie, w jaki sposób ten tekst mógł być realizowany (w czasie oralnego przetworzenia), trzeba odnieść się do obecnego od niedawna w polskiej literaturze przedmiotu przekonania o otwartym charakterze niektórych tekstów średniowiecznych. Najczęściej tę cechę dokumentuje się materiałem kazań, które - jak o najstarszym zachowanym zbiorze pisał Krzysztof Bracha - były „żywym tekstem, otwartym na rozbudowę, uzupełnienia i korektę w czasie ekspozycji werbalnej" (Bracha 2010: 101). Na podstawie analizy wielu kolekcji kazań badacz zauważył, że ,zapisane kazanie było [...] tylko propozycją, modelem, formularzem, a nie «gotowcem» do odtworzenia" (Bracha 2010: 103). Podobnie o Kazaniach świętokrzyskich myślał Tomasz Mika, który zauważył, że „pisana postać kazań mogłaby być - i w wypadku omawianego zbioru najprawdopodobniej była - bardzo odmienna od symultanicznie egzystującego jej ustnego odpo- 
wiednika, «ustnej transmisji»» (2012: 70-71). Także Marek Skwara o Kazaniu II ze wskazanego zbioru pisał, że jest to „rodzaj konspektu-wzoru przeznaczonego do konkretnych, a więc przede wszystkim ustnych realizacji” (2009: 164). Warto zauważyć, że nie tylko zbiory kazań cechuje otwartość. Ten charakter można przypisać również kartom służącym jako pomoc dydaktyczna, czego świadectwem jest jedna karta $\mathrm{z}$ rękopisu Jakuba z Piotrkowa (rękopis Biblioteki Jagiellońskiej, sygn. 1297):

Tego rodzaju zabytki nie tyle są (były) tekstami, co tekstami się stają (stawały). Głośna realizacja $\mathrm{w}$ różnych sytuacjach nadawczo-odbiorczych pozwalała użytkownikowi z tego zbioru składników nieustannie tworzyć nowe różniące się od siebie całości, będące zamkniętymi i zrealizowanymi w określonej sytuacji komunikacyjnej tekstami, mającymi swój początek i koniec, określoną intencję, nadawcę i odbiorcę (Masłej 2015: 237-238).

Dopiero spojrzenie na obserwowany obiekt - fragment tzw. parafrazy Modlitwy Pańskiej Ludolfa z Saksonii - jako na całość oraz przyjęcie założenia o jego otwartości pozwala zobaczyć w nim tekst, który mógł być realizowany na kilka sposobów: w całości po łacinie (z pominięciem zapisków w interlinii), w całości po polsku (z jednoczesnym thumaczeniem odpowiednich fragmentów Ojcze nasz - co w okresie powstania rękopisu było już zadaniem łatwym, pozwalającym zostawić Pater noster w zapisie łacińskim - Masłej 2016) oraz jednocześnie po polsku i po łacinie (tekst podstawowej modlitwy - po łacinie, kolejne wezwania - w języku narodowym).

Jakkolwiek dopiski w interlinii są z punktu widzenia ich miejsca wpisania glosami, to w wypadku tego zabytku można uznać, że tworzą tekst, który został zapisany między wierszami ze względu na jego funkcję. Był on niejako symultanicznym - ale co ważne i odróżniające tego typu zabytki od standardowo rozumianych glos ${ }^{13}$ - pełnym, zachowującym wszystkie cechy źródła, tłumaczeniem tekstu łacińskiego. Polski (lub polsko-łaciński) tekst mógł funkcjonować samodzielnie, bez podstawy, nad którą został dopisany. Przedstawionej tu propozycji nie można w prosty sposób przenieść na pozostałe zabytki tego typu, wydaje się jednak, że i w ich wypadku warto podjąć próbę odpowiedzi na postawione we wstępie pytanie o istotę tego typu zabytków i możliwe sposoby ich oralnej realizacji.

\section{BIBLIOGRAFIA}

Bielawski K., 2002, Ludolf z Saksonii i jego dzieto, „Terminus”, nr 1-2, s. 229-257. Bracha K., 2010, Noty łacińskie w „Kazaniach świętokrzyskich”, „Z Badań nad Książką i Księgozbiorami Historycznymi”, t. 4, s. 91-109.

${ }^{13}$ Problemy definicyjne i terminologiczne są przedmiotem osobnego opracowania - zob. Masłej, Glosa-problemy definicyjne i terminologiczne (w druku). 
Brückner A., 1897, Drobne zabytki języka polskiego, „Rozprawy Akademii Umiejętności”, seria II, t. X, Kraków, s. 206-291.

Brückner A., 1900, Apokryfy średniowieczne. Czesść pierwsza, Kraków.

Dobrzeniecki T., 1965, „Rozmyślania dominikańskie” na tle średniowiecznej literatury pasyjnej, w: Rozmyślania dominikańskie, t. 1, red. K. Górski, W. Kuraszkiewicz, Wrocław-Warszawa-Kraków, s. 39-42.

Gesner A., 2011, Glosy w Rozmyślaniu przemyskim. Wyniki analizy formalnej i perspektywy badań, „Kwartalnik Językoznawczy”, nr 3, s. 89-96.

Heinimann S., 1988, Oratio Dominica romanice. Das Vaterunser in den romanischen Sprachen von den Anfängen bis ins 16. Jahrhundert, Tübingen.

Krążyńska Z., Mika T., Słoboda A., 2015, Składnia średniowiecznej polszczyzny. Czesść I. Konteksty - metody - tendencje, Poznań.

Leńczuk M., 2010, Problemy terminologiczne w opisywaniu glos polskich na przykładzie $X V$-wiecznych tłumaczeń kanonu mszy św., „Kwartalnik Językoznawczy”, nr 2, s. 19-36.

Masłej D., w druku, Glosa-problemy definicyjne i terminologiczne.

Masłej D., 2015, Średniowieczna pomoc dydaktyczna. Studium jednej karty z rękopisu Jakuba z Piotrkowa, ,Terminus”, z. 2, s. 219-240.

Masłej D., 2016, Modlitwa Pańska w polskim średniowieczu. Znad staropolskich rękopisów, Poznań.

Masłej D., 2017a, Głos w dyskusji o tekście staropolskim. Znad kanonów mszy św., „LingVaria", nr 2 (24), s. 93-111.

Masłej D., 2017b, Zbiór glos czy tekst? Kazania augustiańskie jako problem edytorski i naukowy, w: Staropolskie spotkania językoznawcze, t. 2: Jak wydawać teksty dawne, red. K. Borowiec, D. Masłej, T. Mika, D. Rojszczak-Robińska, s. 185-202.

Mika T., 2012, „Kazania świętokrzyskie” - od rękopisu do zrozumienia tekstu, Poznań.

Mika T., 2013, Genetyczna wielowarstwowość i złożoność tekstów staropolskich a ich badania historycznojęzykowe. Rekonesans, ,Biuletyn Polskiego Towarzystwa Językoznawczego", t. LXVIII, s. 131-145.

Mika T., 2015a, Tekst staropolski jako odmienny obiekt badań? W poszukiwaniu narzędzi opisu, „LingVaria”, nr 2 (20), s. 235-250.

Mika T., 2015b, Problemy z Rozmyślaniem przemyskim. Formułowanie sądów ogólnych a wielowarstwowość średniowiecznego tekstu, „LingVaria”, nr specjalny, s. 87-104.

Mika T., Twardzik W., 2011, Jak zagadkowe cztery tytuły rozdziatów w Rozmyślaniu przemyskim pozwalaja wyobrazić sobie jego zagubiony autograf, „Język Polski”, z. 5, s. 321-334.

Opalińska M., 2010, Średniowieczne rękopisy i fatszywi pośrednicy. O edycjach i przektadach staroangielskich parafraz Pater Noster, „Przekładaniec. A Journal of Literary Translation", t. 24, s. 291-326.

Rzepka W.R., Wydra W., 2004, Chrestomatia staropolska: teksty do 1543 r., Wrocław.

Skwara M., 2009, Struktura i sposoby argumentacji $w$ Kazaniu na dzień św. Katarzyny, w: Kazania świętokrzyskie. Nowa edycja. Nowe propozycje badawcze, red. P. Stępień, s. $153-166$.

Stramczewska O., 2015, Ślady wielowarstwowości w „,Rozmyślaniach dominikańskich”. Studium przypadku, w: Staropolskie spotkania językoznawcze, t. 1: Jak badać teksty staropolskie, red. T. Mika, D. Rojszczak-Robińska, O. Stramczewska, Poznań, s. 191-202. Twardzik W., 1994, Glosy w „,Rozmyślaniu przemyskim”, „,Teksty Drugie”, nr 3, s. 155-165. 